Marko Paliaga,

UDK 339.138:334.7>(497.5)

Željko Strunje,

PRELIMINARY PAPER

PRETHODNO PRIOPĆENJE

\title{
RESEARCH OF IMPLEMENTATION OF INTERNAL MARKETING IN COMPANIES IN THE REPUBLIC OF CROATIA
}

\begin{abstract}
Marketing has a strong role in creating products and services offered in the market in today's particularly dynamic and turbulent business environment marked by daily struggle to keep market positions and realise competitive advantages. Unlike external marketing, internal marketing is still insufficiently researched and used in Croatian companies. Internal marketing comprises marketing know-how, skills, tools, methods and techniques used on the internal market (within the company) with the objective of achieving synergistic effect of all employees in conformity with basic targets, the mission and strategies of the company. The focus of this paper is the research of characteristics of internal marketing of companies working in the Croatian market. The aim of the research was to determine, by means of a preliminary research, the implementation of principles and internal marketing concept in Croatia and its representation within Croatian companies. Previous works and experiences published in foreign publications indicate advantages of implementation of this concept within companies in addition to a great impact on creation of competitive advantages, particularly in terms of services, customer satisfaction and loyalty of both customers and companies' own employees.
\end{abstract}

Key words: internal marketing, services marketing, employees, management

\section{INTRODUCTION}

Companies spend most of their time planning marketing activities in relation to users of their products/services in the external market. Do they wonder if similar activities adjusted to the internal market (within the company) may be used with their own employees? Who should be in charge of planning and implementing such activities? What qualities should such person possess and in which department should s/he work? Do Croatian companies even recognise the importance of quality and carefully developed communication within the company? An idea of internal marketing lies on the fact that employees represent the first market for each company. For this reason, employees are the ones who should be educated and informed about their company, its activities and basic objectives, the mission and vision of the company for which their work and, naturally, about benefits and functions offered by products or services of the company to end buyers in external markets. Employees at all levels and in all functions have to be actively included in the process. The basic premise and internal marketing concept are various activities within the company whose primary objective is recognizing company products and services and developing total buyer orientation in all company employees. The role of employees and their relation to the company is decisive in service-based and in manufacturing activities alike, for their work and behaviour affect services for buyers, overall quality, and consequently, the overall sale of products or services (Groenroos, 1990, Gummesson 1995., Matjič, 2002, McDonald and Payne, 1997., Berginc, 2003.). There are numerous models that indicate a correlation between internal and external marketing (Piercy, 2010.). Among other, the function and role of internal marketing is a faster 
acceptance of all activities of external marketing within the company (Berry and Parasurman, 1991.).

Illustration of a possible process of internal marketing within the company

I Phase - Introduction

Company management - active participation and support for the programme of internal marketing

Developing the model of internal marketing

Appointment of project leader, defining objectives, budget and other resources

II Phase - Implementation of process ofinternal marketing

Training and continuous support for employment and education of employees

Unified internal marketing campaign

Management that actively participates in internal marketing campaign, feedback

III Phase - Results of the process

Employees understand their role in the company

Company employees are motivated

Employees are more content

IV Phase - Interaction

Employees interact with external buyers

Noticeably improved quality of service and communication with buyers

Higher buyers' satisfaction through more emphasised competitive advantages

Higher profitability of business activities

Management realises company objectives

Source: authors, partially adapted based on Bašić (2010)

Internal marketing is implemented by leading service based and manufacturing companies (Ballantyne, 2010., Kotler 2000). Some of best practice examples include Johnson \& Johnson, Motorola, Xerox, Merck \& Company, Alcoa, Matsushita and others (William E. Halal, 2000., Kotler, 2000.). As a matter of fact, internal marketing should precede activities of external marketing, because excellent services and customer relations produce employee satisfaction (Sihombing and Gustam 2007.).

\section{REVIEW OF LITERATURE RELATED TO INTERNAL MARKETING}

\section{DEFINITIONS OF INTERNAL MARKETING}

Internal marketing concept emerged and appeared in literature in the early 1970s (Yang, 2010., Rafiq and Ahmed, 2004.). Authors Varey and Lewis (2000.) argue that internal marketing developed from services marketing. Although it has existed for almost thirty years, this concept has not become widely accepted by managers, while its potential benefits are often grossly neglected (Bannon, 2005.). Mornay (2010.) claims that most companies have failed to successfully implement internal marketing concepts due to a lack of knowledge and insufficient understanding of all components and their influences within the company. In short, most previous research of possible application of internal marketing may be viewed through four key aspects: treatment of employees as internal customers (Berry, 1981., Green 1994.), development of employees' orientation towards internal and external customers 
(Piercy and Morgan, 1991.), orientation of internal marketing towards human resource management (Hwang, Chi, 2005.) and development of internal exchange (Bak, 1994.)

Marketing experts have recently focused more attention on internal market, particularly in the second half of the 1990s, aware of the need to balance internal and external marketing as a precondition of successful performance (Groenroos, 1990., Janičič, 1990., McDonald and Payne, 1997., Piercy and Morgan, 1991., Došen, Prebežac, 2000.). Numerous authors argue that successful marketing approach is possible solely if internal and external marketing are integrated into company as a joint and mutually dependent system (Caruana, Calleya, 1998.).

According to the American Marketing Association (AMA), internal marketing is oriented towards company employees and it enables employees to efficiently perform their tasks (Kotler, 2000.). Internal marketing is actually a border between internal organisation and external markets (Gummesson, 2000). Basic activities of internal marketing are internal informing of employees, internal training of employees, creating togetherness, teamwork atmosphere and motivation (Jarvi, 2009.).

Došen and Prebežac (2000.) claim that internal marketing acts as a process of total management of numerous functions in the company. It works in two manners. First, it secures that employees at all levels, management included, understand and experience company business operations and all activities in the light of the environment that generates an awareness of importance of customers. Second, it secures that all employees are prepared and motivated for customer-oriented behaviour. Basic premise of internal marketing is that internal exchange between the company and groups of its employees has to function efficiently as a precondition of successful business activities in the external market. According to Rafiq and Ahmed (2000.), internal marketing is a planned effort used by marketing as an approach to overcome organisational resistance to changes. Its purpose is to organise, motivate, inter-functionally co-ordinate and integrate employees towards the efficient implementation of corporate and functional strategies to achieve customer satisfaction through a process of creating motivated and customer oriented employees. Mornay (2010) maintains that internal marketing is an excellent tool that helps in the implementation of strategic plans.

\section{FUNCTION OF INTERNAL MARKETING AND EMPLOYEE RELATIONS}

Internal marketing works as a twofold process of holistic management of numerous functions in the company.. Internal marketing is a permanent process in the company where the organisation motivates and empowers employees at all levels with the objective of constantly creating a positive experience for customers (Mulhern and Schultz, 2010.).

The function of internal marketing is internal exchange between the company and its employees that has to function efficiently before the company may be successful in realising its objectives related to external market (Gronroos, 1990.). Furthermore, internal marketing has to be viewed both as business philosophy and as a process (Covey, 2000.). Ferguson and Brown (1991.) argue that marketing has a twofold function, namely securing production and sales and caring about its employees. In fact, the original concept of internal marketing is aimed at implementing the philosophy and practice of external marketing to all persons employees serving external customers with the objective of employing and keeping the best personnel and for the best employees to be able to work in the best possible way (Franjić, Šverko 2000.). In addition to the previous premise, authors Križman and Bušelić (2001.) argue that satisfying employee needs has the primary role in satisfying the needs of users of external market because only a satisfied employee will adequately provide quality services to customers. Internal marketing has evolved as a concept due to the need to constantly improve 
all employees involved in production, providing services and customer relations (partially based on Gudmundskon, Lundbreg, 2009.).

\section{INTERNAL MARKETING CONCEPT}

Basic concept of internal marketing is founded on two aspects. First, that each employees has his/her internal customers and that $\mathrm{s} / \mathrm{he}$ is also an internal customer. Second, employers have to secure advantages, benefits and extra services for their employees, make them content, which will lead to better business performance in external markets and customers (Gronroos, 1990.) In addition to internal marketing as a process and concept oriented towards employees within the company (Green, Walls and Schrest, 1994.), internal marketing has recently also been focused on planning and implementing the process of improving all kinds of exchange within the company by coordinating and improving processes of exchange between the company and its employees, between the management and departments, between departments and department employees. According to internal marketing concept, the entire company becomes an internal market through the process of decentralisation and through viewing departments as profit centres, a sort of inter-department competitors (Ballantyne, 2010). Nowadays, internal marketing concept makes internal parts of the company compete with each other, selling and buying like in external markets. Furthermore, internal marketing concept is also oriented towards the transformation of internal employees into internal customers making them each other's customers within the organisation. The whole organisation improves its external customer relations only by satisfying the needs and desires within the company (Piercy and Morgan, 1991., Gronroos 1990., Janičič, 1990., Green, Walls, Schrest, 1994., Snoj and Mumel, 1998.). Internal marketing has to be co-ordinated with external marketing and a marketing-oriented company has to treat it as its priority. Marketing orientation certainly has to be preceded by development, communication and implementation of programmes of external marketing. The above definitions of internal marketing indicate the importance of motivation and satisfaction of employees and creation of internal market and internal customers within the company with the objective of satisfying customers in external markets and realising company objectives, mission and strategy. Such statement is closely related to the object of the present research explained and analysed hereinafter and used in drawing further conclusions about the subject matter.

\section{IMPLEMENTATION OF INTERNAL MARKETING CONCEPTS AND MARKETING MIX}

\section{OBJECTIVES OF INTERNAL MARKETING}

To justify the introduction and use of internal marketing, we need to define clear objectives of internal marketing and precisely explain its concept. Objectives of internal marketing are defined in internal and external market (Snoj, Mumel, 1998., Franjić, Šverko 2000.) There are three basic objectives of internal marketing (Bašić, 2008.): the first objective is related to internal market and it comprises investments in employees so that they feel they belong to the company, understand the vision of the company and its strategic objectives and how they will be realised. The second and third objective are related to external market and they refer to investments in customers geared at developing good long-term business relations and reaching competitive advantages, which is the basic premise for survival of the company in the market struggle. Additional objectives of internal marketing are employee motivation (Gronross, 1991., Hay 1999.), an increase of employee satisfaction (Lings, 1999.), maximizing employee efficiency (Thomson and Whitwell, 1993.), harmonising employee 
relations (Snoj, 1998.), and keeping quality personnel (Green, Walls and Schrest, 1994.). These objectives also explain the understanding of internal marketing concept (partially according to Barry 1981., Gronroos 2002.) as a strategic view of employees as internal customers who perceive their work tasks as internal products that fulfil the needs of internal customers and finally, of external customers. They imply directing and educating employees to keep and create customer-salesman relations, namely customer-oriented employees and mutual synergic effects that produce competitive advantages as the final objective of each company.

\section{INTERNAL MARKETING MIX}

The term marketing mix implies combinations of certain elements used in achieving company objectives and fulfilling customers' needs and desires. Marketing mix includes 4 basic variables: Product, Promotion, Price and Distribution, and recently, particularly in terms of services, the 4 elements are added additional 3 P elements; Process, Personnel and Physical Environment. As with external marketing, internal marketing also comprises the 4 wellknown elements of marketing mix oriented towards the internal market. In this respect, Product denotes policy, programme and service with which the management tries to act on its internal customers-employees, Price refers to the cost of internal programmes, services and policy, Distribution focuses on policies, programmes and services, and Promotion refers to internal sales, internal advertising, internal public relations and publicity, internal incentives and disincentives.

The recognition of elements of marketing mix of internal marketing is indispensable in defining and recognising elements that already exist in the company and, on the other hand, elements that still have to be developed. The table below shows a graphic representation of $4 \mathrm{P}$ elements of marketing mix.

Table 1.

Four elements of internal marketing (4P)

\begin{tabular}{|l|l|}
\hline PRODUCT & $\begin{array}{l}\text { Programmes, policies and services } \\
\text { (education, informing) - everything that has } \\
\text { to be planned and continuously monitored } \\
\text { that is oriented directly to employees. } \\
\text { Research, planning and education are part of } \\
\text { product of internal marketing. }\end{array}$ \\
\hline PRICE & $\begin{array}{l}\text { Price or cost of internal programmes, policies } \\
\text { or services. Every investment has its price. } \\
\text { Cost and benefit ratio of changes has to be } \\
\text { defined. }\end{array}$ \\
\hline PLACE & $\begin{array}{l}\text { Place/location of programme implementation, } \\
\text { policy, services, responsibility for } \\
\text { implementation and submission of } \\
\text { programmes, policies and services }\end{array}$ \\
\hline PROMOTION & $\begin{array}{l}\text { Internal sale, internal public relations, } \\
\text { internal advertising, internal incentives and } \\
\text { disincentives, internal website }\end{array}$ \\
\hline
\end{tabular}

Source: authors, based on (Janičić 1990., Flipo, 1986., Devetak 1999., Bašić, 2008.,) 


\section{ELEMENTS OF INTERNAL MARKETING MIX}

There are four elements that constitute the component of product defined by several authors: selection of employees (Groonroos, 2000., Hogg and Carter, 2000), education and training of employees (Gronroos, 2000., Cahill, 1995.), teamwork (Bak, 1994.) and empowerment of employees. The first element of internal marketing mix is a product that includes policies, programmes, services, research, planning and education related to the improvement of work and activities of all employees-internal customers.

The price of internal marketing mix is the cost of internal programmes, services, education, and research with the objective of their implementation. The price in internal marketing comprises salaries each employee receives on a monthly basis that consist of variable and fixed part, incentives related to successful implementation and application of products of internal marketing mix and awarding system necessary for a successful implementation of the programme of internal marketing.

Flipo (1986.) maintains that distribution refers to the location where activities are performed within the company or in the vicinity of internal customers. Distribution as element of internal marketing mix denotes the place-location of the programme, policies and services that can be related to the company that implements internal marketing. Distribution in internal marketing also comprises the schedule of workplaces, career development and monitoring.

Several authors claim that communication with company employees is the key component in the creation of relations with employees seen as internal customers (Gronroos, 2000., Rafiq and Ahmed, 2000.). Activities of promotion of internal marketing are geared at company's own internal market in terms of promoting internal programmes, policies and services. They comprise the internal improvement of sales, internal public relations, internal advertising, internal promotion and personal contact-personal sales. Media used in internal marketing include personal contacts with each employee, internal e-mails for informing employees, internal website, internal ads and internal newsletter.

A proper definition of elements of marketing mix of internal marketing requires an analysis of the state of the company and known degree of development of elements of marketing mix of internal marketing. This is followed by an explanation of each individual element of marketing mix of internal marketing and elaboration of the proposal of manner of implementation of each element within the company. Definition and explanation of elements of marketing mix are followed by their implementation and, finally, control in the function of monitoring, correcting, developing and adjusting erroneous activities with the objective of providing feedback and insisting on constant improvement. Internal marketing certainly comprises a large number of measures and target groups, so that most companies might be faced with the problem which department should take over the responsibility for internal marketing. There are three possible solutions: establishing a special department for internal marketing, operationalization of internal marketing based on the project principle and individual needs in the company or through the expansion of marketing department. Based on steps proposed for the implementation of marketing mix and organisation of internal marketing, research results and their analysis, the following section will illustrate steps that are or are not implemented in Croatian companies. The authors will eventually propose guidelines for future development of internal marketing in Croatia. 


\section{PRELIMINARY RESEARCH OF IMPLEMENTATION OF INTERNAL MARKETING CONCEPT IN CROATIAN COMPANIES}

\section{DEFINING SCOPE OF RESEARCH AND SAMPLE}

For the needs of the present paper, we have carried out a research of companies in the area of the Republic of Croatia using the selected questionnaire. Questions were structured based on authors' opinions and experience and the pilot research in the Republic of Croatia performed by Inga Bašić (2008.). Our research was carried out on the sample of 1,500 largest companies in the Republic of Croatia based on the number of employees and total revenues according to the database of Business Croatia. We have sent 1,500 questionnaires to e-mail addresses of selected companies. Selected sample provided 155 correctly filled out questionnaires from Croatian middle-sized and large companies, or $10.33 \%$, which suffices for a preliminary research of this type. Nevertheless, considering the size of the sample, there may be certain shortcomings in the interpretation of results. Before the research, the questionnaire was tested on 3 experts that have not participated in the research ${ }^{1}$. Testing of the questionnaire did not reveal any important shortcomings.

The following hypotheses have been made for the needs of the research:

H1: Internal marketing is not a relatively new term in Croatia, both in theory and in practice,

H2: Internal marketing in Croatia has a positive effect on the satisfaction of most employees

H3: Internal marketing in Croatia has a positive effect on organisation, business activities and competitiveness.

The research was carried out solely on large and medium-sized companies with highest revenues presuming that internal marketing could be developed only in most advanced companies. Research was carried out from 01.02.2010 to 01.05.2010.

\section{PRESENTATION OF RESEARCH RESULTS}

The results of the research are shown below, in tables and descriptions. Based on activities, research featured 52.81 of manufacturing and 47.19 of service based companies, an almost equal percentage. According to the number of employees, $71.11 \%$ of companies belong to the category of $50-250$ employees, and $28.89 \%$ to the category of over 250 employees. The questionnaire was filled out only by key persons (management) in charge of marketing, internal marketing, or directly by directors or members of the management board, hereinafter referred to as "respondents".

\section{ORGANISATION OF INTERNAL MARKETING IN CROATIAN COMPANIES}

The results indicate that internal marketing in Croatian companies is mostly organised either as human resources service (24.24\%) or within marketing department $(33.33 \%)$. $34.34 \%$ of respondents indicated that internal marketing is not carried out in proposed services but outside them.

\footnotetext{
${ }^{1}$ Note: the test was carried out by the agency Alphera from Pula and professors of Juraj Dobrila University, 2010.
} 
Table 2

State which business function within your company perform activities of internal marketing

\begin{tabular}{|l|r|}
\hline Answers & in \% \\
\hline No answer & 1.01 \\
\hline Human resources & 24.24 \\
\hline Special unit for internal marketing & 4.05 \\
\hline Within marketing department & 33.33 \\
\hline Not listed & 34.34 \\
\hline I do not know & 3.03 \\
\hline Total: & 100.00 \\
\hline
\end{tabular}

Source: authors' research, 2010, possibility of 1 answer

\section{Range of activities of internal marketing and its integration in Croatian companies}

Results of our research show that persons in charge of internal marketing in Croatian companies for the most part $(57.79 \%)$ concentrate on tasks of informing employees and organising various thematic (internal and external) workshops.

The research indicates a relatively high degree of implementation and integration of internal marketing within the company in as many as $64.45 \%$ of all cases (grades 3,4 and 5), while other respondents stated that in their case the degree was low (grade 1 and 2). The largest obstacles affecting the development and functioning of the system of internal marketing are lack of budget and personnel (35\%), relatively unclear position within the company of persons in charge of internal marketing (24.29\%), lack of interest of the management and administration for internal marketing $(15.71 \%)$. The same percentage $(15.71 \%)$ indicate that employees do not collaborate and support employees in charge of implementation of programme of internal marketing. $80.68 \%$ of respondents believe that implementation and integration of internal marketing within the company successfully affects customer satisfaction in the company. $78.89 \%$ of respondents are convinced that internal marketing directly affects the creation of competitive advantages and successful performance.

The results of our research show that $40.66 \%$ of respondents maintain that all their employees actively participate and support activities of internal marketing, while $59.34 \%$ of respondents believe that their employees do not participate at all or are indifferent to activities of internal marketing. The latter data does not favour Croatian companies and it certainly indicates shortcomings in the implementation and integration of internal marketing within the company. The following table clearly shows serious understanding of the need to implement internal marketing of respondents (management). 
Table number 3

In your company, the management understands internal marketing and instruments of internal marketing:

\begin{tabular}{|l|r|}
\hline Answers & in \% \\
\hline No answer & 0.00 \\
\hline $\begin{array}{l}\text { Very important and decisive for long-term } \\
\text { development of company }\end{array}$ & 40.66 \\
\hline $\begin{array}{l}\text { Important but not significant for company } \\
\text { development }\end{array}$ & 31.87 \\
\hline $\begin{array}{l}\text { Not important, activities are carried out but do not } \\
\text { considerably affect the company }\end{array}$ & 9.89 \\
\hline $\begin{array}{l}\text { Completely irrelevant activities that have to be } \\
\text { cancelled in the future }\end{array}$ & 17.58 \\
\hline Total: & 100.00 \\
\hline
\end{tabular}

Source: Authors' research, 2010.

The above data show importance and understanding of the need to integrate and implement internal marketing within Croatian companies. Only a small percentage, $17.58 \%$ of managements of Croatian companies does not understand the need for internal marketing and maintains it should be cancelled.

\section{Motivation, relation to and understanding of internal marketing in Croatian companies}

The below table states that $68.54 \%$ of respondents believe and claim that internal marketing has a positive effect on their employee satisfaction.

\section{Table 4}

Based on your knowledge and research within the company, estimate the influence of internal marketing on your employee satisfaction:

\begin{tabular}{|l|r|}
\hline Answers & in \% \\
\hline No answer & 0.00 \\
\hline Very important & 20.22 \\
\hline Important & 48.32 \\
\hline Neither important nor irrelevant & 24.72 \\
\hline Completely irrelevant & 6.74 \\
\hline Total: & 100.00 \\
\hline
\end{tabular}

Source: Authors' research, 2010.

An almost identical percentage (66.77\%) refers to employees' better understanding of the vision, mission and strategy of the company thanks to integrated implementation of activities of internal marketing. These employees certainly contribute to productivity and overall results of their companies more than those who do not know the future direction of their career. Furthermore, according to respondents' estimates, activities of internal marketing and its integration within Croatian companies in $71.11 \%$ of all cases contribute to better understanding of objectives and work tasks of company employees. Instruments of internal marketing in the Republic of Croatia are distributed through internal meetings $(27.20 \%)$, intranet -internal network (19.60\%), personal contacts $23.20 \%$ and through adverts, posters and notice boards (17.20\%). It is interesting that in only $10 \%$ of cases, instruments of internal 
marketing are distributed and shown to employees through the website. The most widely used instruments of internal marketing are organised and specialised workshops, short reports to employees, internal meetings and internal newsletter.

\section{Contribution and limitations of results and guidelines for future researches}

All results of the present research indicate a relatively high level of integration and implementation of internal marketing in the Republic of Croatia. It would be interesting to research and compare the implementation of concepts of internal marketing in companies with less than 50 employees. We believe we would get completely opposing results and that the implementation of the set of instruments of internal marketing probably grows with the size of the company expressed by the number of employees and total revenues. The following table presents research results in relation to research hypotheses.

Table 5- Summary presentation of some research results

\begin{tabular}{|c|c|c|}
\hline & Research hypotheses & Research results, $N=155$ \\
\hline H1 & $\begin{array}{l}\text { Internal marketing is not a } \\
\text { relatively new term in Croatia }\end{array}$ & $\begin{array}{l}\text { In } 91 \% \text { of researched companies, there is some } \\
\text { form of organisation of internal marketing. In } \\
64.65 \% \text { of researched companies, there is a } \\
\text { high level of integration of internal marketing }\end{array}$ \\
\hline \multirow[b]{2}{*}{ H2 } & \multirow[b]{2}{*}{$\begin{array}{l}\text { Internal marketing in Croatia has a } \\
\text { positive effect on the satisfaction } \\
\text { of employees }\end{array}$} & $\begin{array}{l}68.54 \% \text { of respondents believe that activities of } \\
\text { internal marketing have a positive effect on } \\
\text { employee satisfaction in their company }\end{array}$ \\
\hline & & $\begin{array}{l}66.77 \% \text { of respondents believe that the } \\
\text { implementation of internal marketing in their } \\
\text { company contributes to better understanding of } \\
\text { the vision, mission and company strategies of } \\
\text { the employees, which makes them secure and } \\
\text { more content. }\end{array}$ \\
\hline \multirow[b]{4}{*}{ H3 } & \multirow[b]{4}{*}{$\begin{array}{l}\text { Internal marketing in Croatia has a } \\
\text { positive effect on organisation, } \\
\text { business activities and } \\
\text { competitiveness }\end{array}$} & $\begin{array}{l}78.89 \% \text { of respondents believe that internal } \\
\text { marketing directly affects the creation of } \\
\text { competitive advantages and successful business } \\
\text { performance }\end{array}$ \\
\hline & & $\begin{array}{l}80.68 \% \text { of respondents believe that the } \\
\text { implementation of internal marketing concepts } \\
\text { has a positive effect on customer satisfaction }\end{array}$ \\
\hline & & $\begin{array}{l}40.66 \% \text { of respondents believe that internal } \\
\text { marketing is important for long-term } \\
\text { development of the company }\end{array}$ \\
\hline & & $\begin{array}{l}71.11 \% \text { of respondents believe that the } \\
\text { implementation of internal marketing helps } \\
\text { their employees understand the objectives of } \\
\text { their company, which directly affects business } \\
\text { results. }\end{array}$ \\
\hline
\end{tabular}

Source: authors, 2010.

In terms of the above results, the situation in observed Croatian companies may be evaluated as positive. Internal marketing has been recognised as a need, and a large number of activities and instruments are used in the observed companies. As a mater of fact, researched companies 
recognise internal marketing. In most cases, respondents maintain that activities of internal marketing directly affect satisfaction of their customers. By the same token, most respondents believe that activities of internal marketing contribute and directly affect the improvement of competitive advantages of their company. Consequently, the present research indicates and confirms the fact that activities of internal marketing undoubtedly have a positive effect as a tool of motivation, which is reflected on a high degree of active participation of employees in activities of internal marketing.

Through the statement "internal marketing affects satisfaction of customers of our company" and the results expressed herein, we can conclude that a large majority of all respondents is aware of the importance and impact of internal marketing both on employee satisfaction and on the consequent satisfaction of users of products and services in the external market. Besides, respondents maintain that activities of internal marketing for the most part significantly affect employees' enhanced understanding of the company vision, mission and objectives and their proper understanding of work tasks.

The research also indicated that respondents believe there is still a relatively high degree of employees' lack of understanding of activities of internal marketing- $31.87 \%$ (indifferent regardless of activity) and of the management (17.58\% of managers claim that activities of internal marketing are irrelevant, Table $\mathrm{n}$. 3) who in $49.54 \%$ of all cases believe that activities of internal marketing are important but not decisive for the company (Table n. 3). The largest obstacles for the implementation of internal marketing are still a lack of budget for the implementation of activities of internal marketing (18.57\%), according to previous researches, $11.61 \%^{2}$, unclear position of employees in charge of works of internal marketing - either within human resource department or in marketing department $(25 \%)$, and lack of interest of the management and employees with the same percentage (15.71\%), according to previous researches, undefined objectives and tasks of internal marketing ( $28 \%$ of respondents $)^{3}$.

The above results lead to the conclusion that the first step towards a more intense and efficient removal of barriers would certainly be more intense education of the management about needs and results that may be achieved using a systematic application of instruments of internal marketing. Besides, persons within the company in charge of implementing activities of internal marketing should dedicate more attention to their colleagues and employees in terms of better marketing and understanding benefits and results of an integrated system of internal marketing through measurable indicators of efficiency. All companies should collaborate with experts in the field of internal marketing to create and implement the most efficient programmes and activities. In that case, neither engagement nor securing budget would be limiting factors for the implementation.

\section{FINAL CONSIDERATIONS}

Internal marketing is based on seeing employees as internal customers, activities and work tasks are seen as internal products aimed at offering internal products that meet needs and desires of internal and external customers to achieve company objectives. The goal of internal marketing is focusing attention of employees on those internal activities that need to be developed, maintained and improved for the purpose of company performance and strengthening the company in external market. New manners of work undoubtedly require that companies and employees continuously acquire new knowledge and skills -construction of the company with permanent education will be increasingly important in the future. In this context, internal marketing concept focused on continuous improvement of employees and

\footnotetext{
${ }^{2}$ Note: Inga Bašić, M.A., research results for the need of M.A. thesis "Interni marketing u funkciji motiviranja zaposlenika”, University of Zagreb, 2008., p. 101

${ }^{3}$ Ibid., 2008., p. 101
} 
their understanding of the company for which they work will be decisive in the creation of highly competitive and advanced companies.

Research results show a high level of implementation and understanding of internal marketing concept in Croatian middle-sized and large companies. By the same token, results indicate a high correlation between the understanding and support of the management to internal marketing and the impact of internal marketing on employee satisfaction. A premise that requires further consideration is that the degree of integration and applicability of internal marketing increases with the size of company, the number of employees and total revenues. Results of the present research show that Croatian companies do not significantly stay behind in terms of implementation and understanding of internal marketing compared to companies of the neighbouring European countries. Further efforts and research should be performed in order to find measurable effects of activities of internal marketing so that its development and implementation in Croatian companies might increase and expand.

\section{BIBLIOGRAPHY}

1. Ballantyne, David: "A relationship mediated theory of internal marketing", Swedish school of economics and business administration, Helsinki, Finland, www.hanken.fi, 11.01.2010.

2. Bašić, Inga: "Interni marketing-konkurentska prednost poduzeća“, www.posao.hr, 15.01.2010.

3. Bašić, Inga: "Interni marketing u funkciji motiviranja zaposlenika", M.A. thesis, University in Zagreb, 2008., p. 101

4. Bannon, Declan P.: "Internal marketing and political marketing", Paisley Business School, University of Paisley, PSA, 2005.

5. Bateson, J.E.G: "Managing services marketing“, Dryden Press, Orlando Fl, 1992., p. 269.

6. Berry, L.L: "The employee as customer", Journal of Retail Banking, vol. 3., March 1981.

7. Berry L.L., Parasurman A, Zeithaml V.: "Refinement and reassessment of the SERVQUAL scale“, Journal of Retailing 67, 4, pp.420-450., 1991.

8. Berginc, Dario: "Upravljanje odnosov: Prispevek k interdisciplinarnosti trženjske znanosti“, Akademija MM, 10, pp.31-40, 2003.

9. Bradley R. Barnes, Martin T Fox, D.S. Morris: "Exploring the linkage between internal marketing, relationship marketing and service quality: a case study of a consulting organisation“, Routledge, Total Quality Management, vol. 15., No. 5-6, 593-601, July-August 2004.

10. Bak, C.A., Voght, L.H., et.al.: "Management by team: an innovative tool for running a service organisation through internal marketing“, Journal of Service Marketing, vol. 8., No 1, pp 37-47, 1994.

11. Caurana A., Calleya P.: "The effect on internal marketing on organisational commitment among retail bank managers", International Journal of bank marketing, vol 16., no 3, pp. 108-116., 1998.

12. Covey Stephen R: "Načela uspješnog vođenja“, Ljubljana, Mladinska knjiga, p.276, 2000.

13. Devetak Gabrijel: "Temelji trženja in trženjska zasnova podjetij“, Koper, Visoka šola za menedžment, p. 2002, 1999.

14. Flipo, Jean Paul: "Service firms: independence of external and internal marketing cervices", European Journal of Marketing 20, 8, pp.5-13, 1986. 
15. Ferguson, J.M.; Brown, S.W.: "Relationship marketing and association management", Journal of Professional Services Marketing“, Journal of Professional Services Marketing, vol. 7, No 2, pp.137-147, 1991.

16. Gronroos, Christian: "Defining marketing: a market oriented approach", European Journal of Marketing, 23, 1, pp. 34-39., 1991.

17. Gronroos, Christian: "Service management and marketing-managing the moments of truth in service competition", Maxwell MacMillan International Edition, Lexington Books, Lexington Mass, 1990, p. 222.

18. Gronroos, Christian: "Service management and marketing: a customer relationship approach“, 2nd edition, John Wiley \& Sons, Ltd. Chichester, 2000.

19. Gudmundson Anna, Lundberg Christine: "Internal marketing, a way of improving service quality“, ETOUR, Ostersund, Sweden, 2009.

20. Gummesson Evert: "Internal marketing in the light of relationship and network organisations“" Internal Marketing, Routledge, New York, 2000., p. 27

21. Gummesson Evert: "The new marketing-developing long term interactive relationships“, Marketing Strategies-New Approaches, New Techniques, Pergamon, Oxford, pp. 83-102, 1995.

22. Green, W.E., Walls, G.D., Schrest, L.J.: "Internal marketing-the key to external marketing success", The Journal of Services Marketing, 8, 4, pp. 5-13, 1994.

23. Halal Wiliam: "From hierarchy to enterprise-internal markets are foundation for a knowledge economy“", Internal Marketing, Routledge, New York, 2000., p.8.

24. Hog, G. Carter S.: "Employee attitudes and responses to internal marketing", Internal Marketing Directions for Management, Routledge, London, pp. 109-124, 2000.

25. Hwang Ing San, Chi Der Jang: "Relationship among internal marketing, employee job satisfaction and international hotel performance, empirical study", International Journal of Management, vol. 22, no. 2, June 2005., pp. 285-293.

26. http://www.marketingpower.com/_layouts/Dictionary.aspx?dLetter=I, 15.12.2009.

27. Jarvi, Pentti: "Internal marketing and commitment of the employees when managing the customer oriented business", School of Business and Economics, University of Jyvaskyla, Finland, 2009.

28. Janičić, Zlatko: "Marketing strategija menjave“, Gospodarski vjesnik, Ljubljana, 1990.

29. Kotler, Philip: "Marketing management", NJ, Prentice Hall, 2000.

30. Križman Pavlović, Bušelić: "Interni marketing - imperativ kvalitete usluga javnih službi“, Proceedings Marketing države-marketing hrvatske države, CROMAR, Pula, 2001, p. 61.

31. Lings, Ian: "Managing service quality with internal marketing schematics", Long Range Planning, 32,4, pp. 453-463., 1999.

32. Ozretić Došen, Prebežac: "Interni marketing u uslužnim poduzećima, primjer zrakoplovnih kompanija“, Journal Acta Turistica, School of Business and Economics Zagreb, June 2000, no. 1, p. 20.

33. Matajič, Mateja: "Trženje temelječe na odnosih med podjetji, v slovenskih razmerahkonceptualni modle in empirična prevreba“, Akademija MM, 9, pp. 29-44, 2002.

34. Mornay Roberts Lombard: "Employees as customers-an internal marketing study of the AVIS car rental group in South Africa", African Journal of Business Management, vol. 4(4), pp. 362-372, April 2010.

35. McDonald, Malcolm, Payne Adrian: "Marketing Planning“, Butterworth Heinemann, Oxford, 1997.

36. Mulhern Frank, Schultz Don: "Internal marketing best practise study" www.performanceforum.org/fileadmin/pdf// , 11.11.2010. 
37. Piercy, Nigel;Morgan, Neil: "Internal marketing-the missing half of the marketing programme“, Long Range Planning, 24, 2, pp. 82-93,1991.

38. Piercy, Nigel F: "Marketing implementation, organisational change and internal marketing strategy“, download IT, www.download-it.org/learning resources.php, 11.11.2010.

39. Rafiq M;Ahmed P.K.: "Advances in the internal marketing concept: definition, synthesis and extension“"Journal of services marketing, vol. 14, no. 6., 2000, p. 453.

40. Sihombing Simona, Maredo Gustam: "The effect of internal marketing on job satisfaction and organisational commitment", University of Pelita Harpan, Karawaci, The 1 PPM National Conference on Management Research, November 2007.

41. Snoj, Boris; Mumel, Damjan: "Da li stupanj konkurencije okolini utječe na intenzivnost upotrebe aktivnosti i iz područja internog marketinga?", Akademija MM, 1997.

42. Snoj, Boris: "Menedžment usluga“, Koper, Visoka škola za menedžment, p.186, 1998.

43. Šverko, Ivan; Franjić Zoran: "Internal marketing in profit and non-profit organisations, contribution to democratisation", 25th annual macromarketing conference; "Macromarketing contribution to democratisation and socio-economic development", Lovran, June 22-25, 2000.

44. Šverko, Ivan, Franjić, Zoran: "Interni marketing u funkciji razvoja tržišne demokracije", International Scientific Symposium; "Market democracy in Croatia situation and prospects", Varaždin, 26-27 October 2000, published in conference proceedings "Market democracy in Croatia - situation and prospects", Varaždin, pp. $287-303$.

45. Thomson, Kevin: "Managing your internal customer-the key to getting better results", Financial Times, London, 1996.

46. Voima, Paivi; Christian Gronroos: "Internal marketing-a relationship perspective“, V.J.Baker, Encyclopaedia of marketing, Thomson International, pp. 747-751, 1999.

47. Varey R.J., Lewis, B.R: "Internal marketing, directions for management", London, Routledge, 2000.

48. Yang, Jen-Te: "Development and emergence of the internal marketing concept", Department of Hotel and Restaurant Management, National Kaohsiung Hospitality College, Taiwan, http://www.hicbusiness.org/biz2003proceedings/JenTe\%20Yang.pdf, 01.11.2010.

\section{Other used unmentioned sources:}

49. Rajyalakshmi Nittala, A. Vijaya Kameswari: "Internal marketing for customer satisfaction in retail sector", Dept. of Commerce and Management Studies, volume 3, number 3, September 2009, pp. 207-220, http://www.pdftop.com/ebook/internal+marketing/ 15.11.2010.

50. Anne Souchon and Ian Lings, Aston University: "Adopting internal marketing practices across national borders: key propositions and implications", http://www.pdftop.com/ebook/internal+marketing/ 15.11.2010

51. Forum for People Performance Management and Measurement, Internal Marketing Best Practice Study, http://www.pdftop.com/ebook/internal+marketing/, 16.11.2010.

52. Survey Results, Training Efficiency: Internal Marketing, http://www.pdftop.com/ebook/internal+marketing/, 16.11.2010. 


\title{
ISTRAŽIVANJE IMPLEMENTACIJE INTERNOG MARKETINGA U PODUZEĆIMA U REPUBLICI HRVATSKOJ
}

\begin{abstract}
SAŽETAK
Marketing ima važnu ulogu u stvaranju proizvoda i usluga prisutnih na tržištu današnjeg izrazito dinamičnog i turbulentnog poslovnog okruženja kojeg označava svakodnevna borba za zadržavanje tržišnih pozicija i ostvarivanje konkurentne prednosti. Za razliku od vanjskog marketinga, unutarnji marketing je još uvijek nedovoljno istražen i korišten u hrvatskim poduzećima. Interni marketing uključuje know-how, sposobnoti, alate, metode i tehnike koje se koriste na internom tržištu (unutar poduzeća) s ciljem ostvarivanja sinergije svih zaposlenih u skladu s temeljnim ciljevima, misijom $i$ strategijama poduzeća. Ovaj rad je usredotočen na istraživanje karakteristika internog marketinga u poduzećima prisutnim na hrvatskom tržištu. Cilj istraživanja je odrediti, putem preliminarnog istraživanja, implementaciju principa $i$ koncepta internog marketinga u Hrvatskoj $i$ njegovu zastupljenost u hrvatskim poduzećima. Prethodni radovi i iskustva objavljeni u stranim publikacijama ukazuju na prednosti implementacije ovog koncepta unutar poduzeća uz snažan utjecaj na stvaranje konkurentne prednosti, osobito u pogledu usluga, zadovoljstva potrošača i odanosti kako klijenata tako i zaposlenika poduzeća.
\end{abstract}

Ključne riječi: interni marketing, marketing usluga, zaposlenici, management 